Journal of Zhejiang University-SCIENCE A (Applied Physics \& Engineering)

ISSN 1673-565X (Print); ISSN 1862-1775 (Online)

www.zju.edu.cn/jzus; www.springerlink.com

E-mail: jzus@zju.edu.cn

\title{
Review:
}

\section{Engineering research in fluid power: a review*}

\author{
Hua-yong YANG, Min PAN ${ }^{\dagger+}$ \\ (The State Key Laboratory of Fluid Power Transmission and Control, Zhejiang University, Hangzhou 310027, China) \\ ${ }^{\dagger}$ E-mail: mpan@zju.edu.cn \\ Received Mar. 16, 2015; Revision accepted Apr. 28, 2015; Crosschecked May 13, 2015
}

\begin{abstract}
This article reviews recent developments in fluid power engineering, particularly its market and research in China. The development and new techniques of the pump, valve, and actuator are presented in brief with a discussion of two typical modern fluid power systems, which are the switched inertance hydraulic system and the hydraulic quadruped robot. Challenges and recommendations are given in four aspects including efficiency, compactness and integration, cleanliness, and fluid power education.
\end{abstract}

Key words: Fluid power, Pump/Motors, High-speed switching valve, Digital fluid power, Chinese market doi:10.1631/jzus.A1500042

Document code: A

CLC number: U262.32

\section{Introduction}

In fluid power engineering, hydraulics is used for the generation, control, and transmission of power by the use of pressurized liquids. Fluid mechanics provides the theoretical foundation for hydraulics. Hydraulic topics range through some areas of science and most engineering modules, and cover concepts such as pipe flow, fluidics, fluid power motion control, pumps, valves, actuators, turbines, hydropower, computational fluid dynamics, and flow measurement.

In 1993, Prof. Backé had a presentation with the topic 'The Present and Future of Fluid Power' in the eightieth Thomas Hawksley Memorial Lecture in London (Backé, 1993). He traced the developments of fluid power from the formulation of the fundamental law of hydrostatics to the hydraulic applica-

\footnotetext{
${ }^{\ddagger}$ Corresponding author

* Project supported by the Fundamental Research Funds for the Central Universities (No. 2015FZA4001), and the Youth Funds of the State Key Laboratory of Fluid Power Transmission and Control (No. SKLoFP_QN_1502), China

(DD ORCID: Min PAN, http://orcid.org/0000-0002-2901-3388

(c) Zhejiang University and Springer-Verlag Berlin Heidelberg 2015
}

tions of today. In the last few decades technology has advanced and many more uses have been found for fluid power. He addressed the challenges from the other power generation and transmission methods, such as mechanical and electrical, to fluid power and the possibilities for further development of fluid power, as shown in Fig. 1. It includes three main aspects: utilization of the advantages of fluid power, compensation of the disadvantages of fluid power, and use of the advantages of other technologies to improve fluid power technology. He also concluded the presentation with a prognosis of the possible future development of fluid power, as shown in Table 1. With over 20 years development in fluid power after Backé's talk, it can be seen that he accurately predicted the trend and directions of fluid power. Efficient and smart design fluid power systems are now in very high demand worldwide. Researchers and engineers aim at developing high-efficiency, environment-friendly, and user-friendly fluid power components and systems.

Later, in 1995, at the eighty-third Thomas Hawksley Memorial Lecture, Prof. Burrows pointed out that many of the current applications of fluid power can be traced to ideas embedded in the pioneering work of Bramah, who is best known for 
having invented the hydraulic press, and later contributors (Burrows, 1996). The technological innovations in sensors, materials, computers, and electronics in fluid power were emphasized in his talk. He also stated that exciting challenges and opportunities for fluid power systems lay ahead in the twenty-first century. New fields of activity could have an impact on fluid power, like micro-fabrication technologies and novel material technologies. It was clear that fluid power research will be multidisciplinary. Prof. Edge gave a lecture at an Ordinary Meeting of the UK Automatic Control Council held in London in 1996. The lecture was titled 'The control of fluid power systems - responding to the challenges', which discussed the research on the control of fluid power systems, strengths, and disadvantages of different schemes for control at both component and system levels (Edge, 1997). He concluded the lecture with a summary of the factors and areas of activity in fluid power control, as shown in Fig. 2. It well summarized and predicted the research emphasis and trends in the fluid power control area.

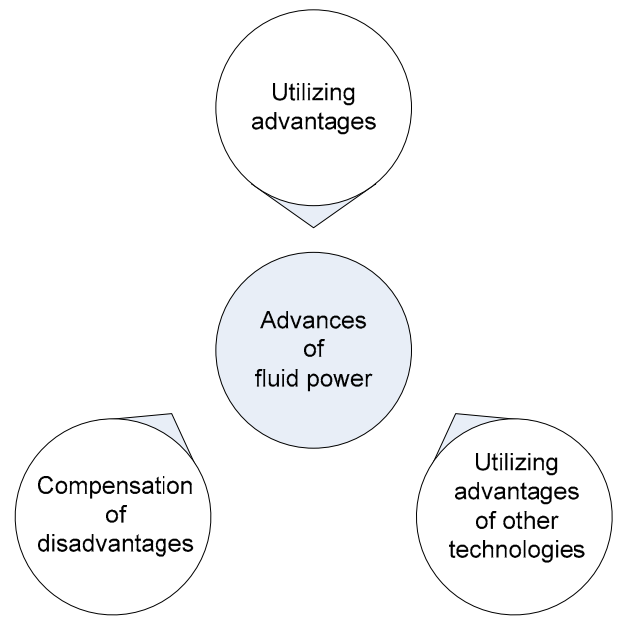

Fig. 1 Development of fluid power (Backé, 1993) Reprinted from (Backé, 1993), Copyright 1993, with permission from SAGE

On the other hand, researchers realized that challenges still exist (Burrows, 2000; Murrenhoff, 2007). System efficiency, noise, and leakage problems raised a lot of attention. Computer-based tools and methods are critical and important for system synthesis (Krus et al., 1994). The development of specialist computer software packages integrated with control packages can offer powerful tools for modeling complex systems and assembling virtual prototypes (Krus et al., 1991). The development of control theory/techniques for fluid power systems has also attracted much interest, for model uncertainty and parameter variations is of major significance in the design. Thirdly, an understanding of occurring physical phenomena in fluid power systems, such as cavitation and pressure ripples, is needed to allow researchers to develop better and more accurate models (Burrows, 2000).

Table 1 Prognosis of the possible future development of fluid power (Backé, 1993)

\begin{tabular}{|c|c|}
\hline No. & Possible future development \\
\hline 1 & $\begin{array}{l}\text { Intensified application of computer programs to } \\
\text { optimize motion, flow, noise, and mechanical } \\
\text { properties }\end{array}$ \\
\hline 2 & $\begin{array}{l}\text { Application of new materials: coatings, ceramics, } \\
\text { and plastics to improve wear resistance and } \\
\text { tribological properties }\end{array}$ \\
\hline 3 & $\begin{array}{l}\text { Application of energy-saving components and } \\
\text { systems: (a) Intelligent pressure supply adapt- } \\
\text { ing pressure and flow to the demand of the } \\
\text { consumers (e.g., load sensing); (b) Intensified } \\
\text { use of variable displacement units with high } \\
\text { efficiency }\end{array}$ \\
\hline 4 & $\begin{array}{l}\text { Further development of sealing and joint tech- } \\
\text { niques to minimize leakage }\end{array}$ \\
\hline 5 & $\begin{array}{l}\text { Development and use of biological degradable } \\
\text { pressure fluids }\end{array}$ \\
\hline 6 & Use of oil-free compressed air in pneumatics \\
\hline 7 & $\begin{array}{l}\text { Separation of fluid power circuit and electronic } \\
\text { signal circuit for high-quality applications }\end{array}$ \\
\hline 8 & $\begin{array}{l}\text { Tendency to fully digitized signal circuit with } \\
\text { digital interfaces for signal input and output }\end{array}$ \\
\hline 9 & $\begin{array}{l}\text { Intensified application of modern control concept } \\
\text { with adaption to changes of open-loop properties }\end{array}$ \\
\hline 10 & $\begin{array}{l}\text { Integration of component-related electronics and } \\
\text { sensors into devices, e.g., variable displace- } \\
\text { ment units, cylinders, and proportional valves }\end{array}$ \\
\hline 11 & $\begin{array}{l}\text { Tendency to self-sufficient electrohydraulic or } \\
\text { electropneumatic axis drives with bus interface }\end{array}$ \\
\hline
\end{tabular}

To respond to the challenges and speed up the development of fluid power technology, the National Fluid Power Association (NFPA), the American Trade Association, the Japan Fluid Power System Society (JFPS), and several Fluid Power Trade Associations in Europe, announced research priorities for fluid power (Burrows, 2004). There is certainly widespread interest in researching and studying fluid power in a system or mechatronics context. In the 
last 20 years in China, the extensive infrastructure and construction programs increased investment in industrial automation, the huge potential internal market for agricultural machinery, construction machinery, and food processing equipment, all point to an anticipated high growth in demand for fluid power technology.

This paper reviews recent technology in the fluid power area at both component and system levels. It includes the development of components, such as pump, valve, and actuator and the novel conception and application of fluid power systems. It also emphasizes the rapid development of the fluid power area and details university research activities and industrial production recently in China. Challenges and recommendations are presented with a concern for fluid power education in China, followed by conclusions.

\section{Fluid power components and systems}

\subsection{Typical hydraulic components: pump, valve, and actuator}

Hydraulic pumps supply fluid to the components in the system. Pressure in the system develops in reaction to the load. It means a pump rated for $30 \mathrm{MPa}$ is capable of maintaining flow against a load of about $30 \mathrm{MPa}$ with a low system pressure loss and leakage. Also, pumps have a power density about 10 times greater than an electric motor in terms of volume efficiency. Common types of hydraulic pumps are listed in Table 2. Therefore, pump design techniques, efficiency, reliability, price, and operating conditions are researched by many groups and industries. Modern pump techniques are desirable as the 'heart' of the hydraulic machinery.

Effective approaches, or models for studying pump characteristics, are developed by researchers continuously. Some pioneering work on calculating the cylinder pressure during the trapping period between ports was proposed by Yamaguchi (1966). In his work, the efficiencies of pumps and motors were defined with the compressibility of flow, trapping, and relief grooves. The effect of relief groove design on pump power losses and pump noise can be predicted by using this model. This model has been referred to, and successfully applied in lots of further research (Zeiger and Akers, 1985; Schoenau et al., 1990; Manring and Zhang, 2001; Manring, 2003). A comprehensive study of the design and analysis of hydrostatic pumps and motors is described in

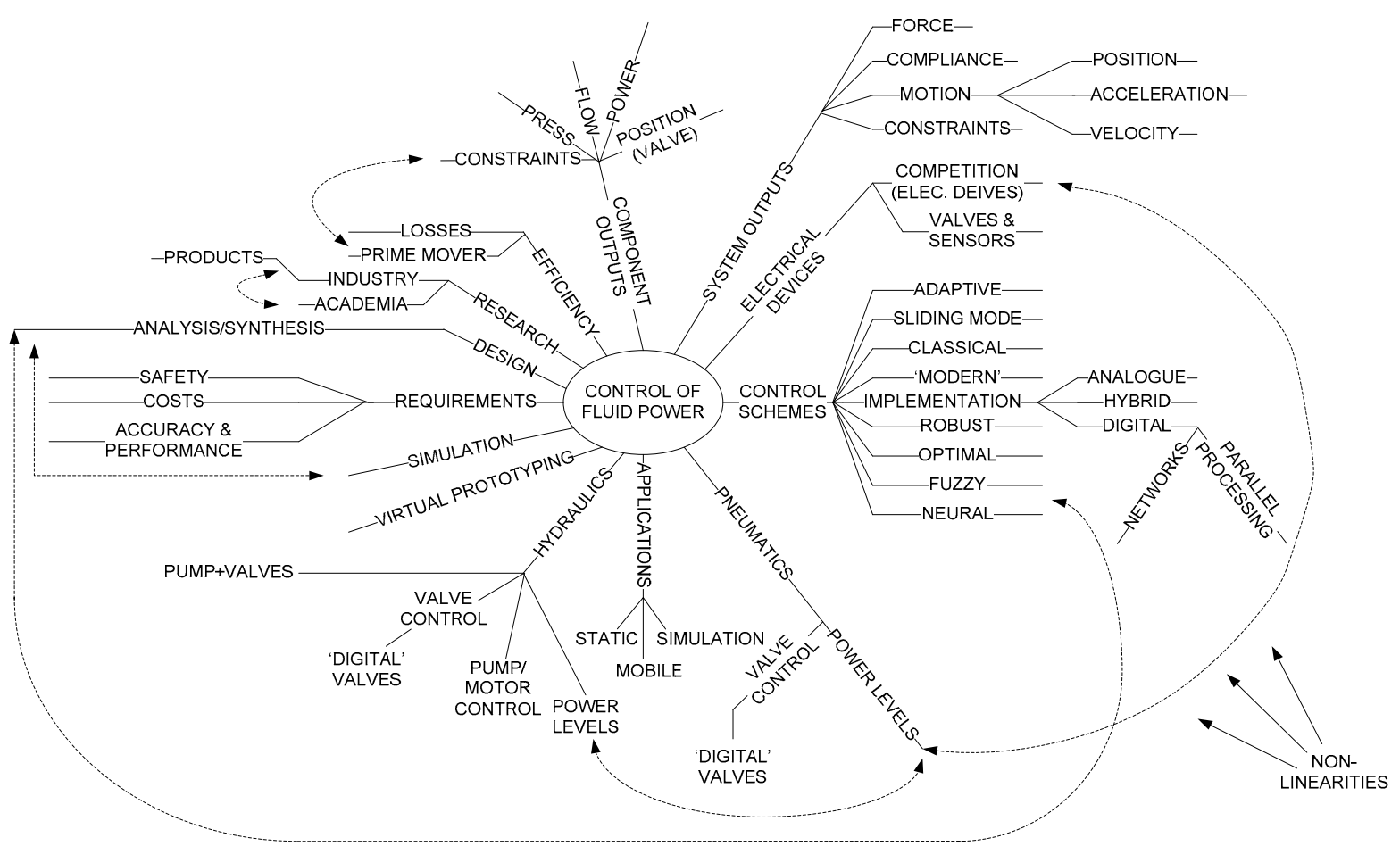

Fig. 2 The domain of fluid power control (Edge, 1997)

Reprinted from (Edge, 1997), Copyright 1997, with permission from SAGE 
Table 2 Common types of hydraulic pumps (Watton, 2009)

\begin{tabular}{|c|c|c|c|c|c|}
\hline Pump type & Mechanism & Efficiency & Reliability & Working conditions & Price \\
\hline Gear pump & $\begin{array}{c}\text { Simple, constant } \\
\text { displacement }\end{array}$ & Low efficiency & Durable & $<20 \mathrm{MPa}$ & Cheap \\
\hline Vane pump & $\begin{array}{r}\text { Simple, positive } \\
\text { displacement }\end{array}$ & Good & Reliable & $\begin{array}{l}\text { Good for high-flow, low-pressure } \\
\text { output }\end{array}$ & Reasonable \\
\hline Piston pump & $\begin{array}{c}\text { Complex, variable } \\
\text { displacement }\end{array}$ & High efficiency & Reliable & $\begin{array}{l}\text { Rated high pressure; good for } \\
\text { high-pressure, low-flow output }\end{array}$ & Expensive \\
\hline
\end{tabular}

(Ivantysyn and Ivantysynova, 2003), which provides the understanding of the working principles of pumps and motors and the design of displacement machines in accordance with the state-of-the-art analysis and modern design methods.

In the last 10 years, pump optimization research has been gradually increased in terms of pump efficiency, power loss, and noise level. Many useful tools have been developed for analyzing and optimizing pump performance. A simulation tool CASPAR for the calculation of the non-isothermal gap flow in the connected gaps of swash plate type axial piston machines has been developed (Wieczorek and Ivantysynova, 2002). It is an effective and useful approach to support the development of the pump. CASPAR allows the improvement of the efficiency of swash plate machines by optimization of the gap macro geometry without lengthy testing (Lasaar and Ivantysynova, 2002). However, the software only considers viscous friction, and elasto hydrodynamic effects are not considered. Using CASPAR, for example, the tribological system formed by the piston/ cylinder assembly of swash plate axial piston machines, and the influence of a piston macro and micro geometry variation on energy dissipation can be effectively investigated (Ivantysynova and Lasaar, 2004). Besides CASPAR, some particular tools, such as HYGESim (HYdraulic GEar machines Simulator), are being developed for analyzing gear pump performance with high accuracy of simulation (Devendran and Vacca, 2013). It is a multi-domain simulation model for the detailed analysis of external gear machines. HYGESim was successfully utilized to optimize the design of the grooves on the lateral bushes presented in (Vaseena and Vacca, 2010) and an external spur gear pump shown in (Devendran and Vacca, 2013).

The future research areas and challenges for pump and motor design will include the accuracy of the pump and motor mathematical model (Eaton et al., 2006), novel design, and optimization techniques (Mauck et al., 2000). Also, high bandwidth pump control techniques will be more and more addressed and investigated in further research (Ivantysynova, 2008). The trend in pump design is gradually moving towards high efficiency, low noise, compactness, and light weight.

Hydraulic control valves are designed to route the fluid to the desired actuator in systems. They usually consist of a spool which can slide to a different position in the housing to control the fluid. The spool position may be actuated by mechanical levers, hydraulic pilot pressure, or solenoids which push the spool left or right. They can be catalogued in different ways in terms of their design techniques, functions, and materials. It is widely recognized that the control valve is one of the most expensive and sensitive parts of a hydraulic circuit.

For example, a high-speed on-off valve is essential for modern digital fluid power systems. Control using high-speed and high flowrate on-off valves has been proposed as a way to significantly improve the efficiency of fluid power systems over a conventional valve control approach in switched inertance hydraulic systems (SIHS) (Pohl et al., 2001; Scheidl et al., 2008a; 2008b; Johnston, 2009; Pan et al., 2014a; 2014b). This will be described in Section 2.2. Cao et al. (2005) suggested that energy can be lost in an on-off valve system as a result of valve transition times, fluid compressibility, pressure drops across the on-off valves, and hysteresis in the accumulator bladder, fluid friction, and leakage. A technology for the smart-design of the high bandwidth on-off valve is desirable. A four-way rotary valve was developed by Brown et al. (1988) with a desired switching frequency of $500 \mathrm{~Hz}$. Winkler (2004) later presented a high flowrate and low resistance poppet valve that used multiple metering edges to provide a flowrate 
of $45 \mathrm{~L} / \mathrm{min}$ at a pressure drop of just $0.5 \mathrm{MPa}$. The valve spool was driven by a solenoid with a rise time of approximately $1 \mathrm{~ms}$. Tu et al. $(2007 ; 2012)$ described a fluid driven pulse width modulation (PWM) on/off valve based on an unidirectional rotary spool. The valve was expected to give a flowrate of $40 \mathrm{~L} / \mathrm{min}$ with a low-pressure drop $(0.62 \mathrm{MPa})$, and high speed of $2.8 \mathrm{~ms}$ (transition time at $100 \mathrm{~Hz}$ PWM frequency). A seat type valve, which switches on and off within $1 \mathrm{~ms}$ at a nominal flowrate of $100 \mathrm{~L} / \mathrm{min}$ at $0.5 \mathrm{MPa}$ pressure drop, was also developed by Winkler and Scheidl (2007). Kudzma et al. (2012) proposed a 3-way linear-acting high-speed valve which enables low flow resistance $(65 \mathrm{~L} / \mathrm{min}$ at $1.0 \mathrm{MPa}$ ) and fast switching speed of $0.69 \mathrm{~ms}$, low leakage and very high flow gain. Such high-speed valves give opportunities for improvements in the efficiency of modern digital hydraulic systems (Kogler and Scheidl, 2008).

More generally, modern valve modeling and design approaches have developed rapidly in the last few decades.

Poppet type metering valves have many advantages, including low leakage, and an economical design and control design is challenging as the metering element is not hydrostatically balanced (Fales, 2005). It is also found that minor geometric differences in the poppet valve can result in very different valve characteristics. In particular, there is a very strong dependence upon the width of the contact area between the poppet and its seat (Johnston et al., 1991). Numerical simulation of fluid flow in poppet valves was studied in (Vaughan et al., 1992), and nonlinear and linear models for the dynamic analysis and design of the poppet valve were proposed in ( $\mathrm{Fa}-$ les, 2006; Muller and Fales, 2008; Opdenbosch et al., 2009). These offer effective tools for investigating the performance of poppet valves. Also, newly developed materials were used in the valve development in order to improve valve performance (Tao et al., 2002; Wang et al., 2011). Moreover, various control schemes for controlling hydraulic poppet valves and compensation have been proposed to achieve high bandwidth, fast response, and robustness (Opdenbosch et al., 2004; 2008; Xiong et al., 2015). As can be seen, the poppet valve is a very typical hydraulic component and is widely used in industry. The research of the poppet valve can help researchers and engineers get a better understanding of the operation and physical phenomena of the valve and offer clever industrial solutions.

High-speed solenoid valves have been widely used for their good performance, fast response, and high energy efficiency. A nonlinear dynamic model of a high-speed direct acting solenoid valve was presented in (Vaughan and Gamble, 1996). The solenoid was modeled as a nonlinear resistor/inductor combination, with inductance parameters that change with displacement and current. The spool assembly was modeled as a spring/mass/damper system. This model can accurately predict the spool displacement of a proportional solenoid valve to a voltage input. It enables the development of a new valve from design to performance evaluation before the manufacture of a prototype. In the meantime, methodologies for nonlinear modeling, parameter determination, and performance evaluation of high performance solenoid valves are studied to speed up the design and optimization (Khoshzaban Zavarehi, 1999; Sohl and Bobrow, 1999; Reuter et al., 2010).

New techniques are also investigated for the development of hydraulic actuators that use hydraulic power to facilitate mechanical operation. For example, piezoelectric material has been used in actuators in terms of the usage of the piezoelectric effect (Sirohi and Chopra, 2003). Also, various adaptive control schemes for manipulating hydraulic actuators have been proposed. Earlier research focused primarily on linear control theory. A robust adaptive controller applied to hydraulic servo systems for noncircular machining was introduced in (Tsao and Tomizuka, 1994), and another robust adaptive control scheme was devised in (Plummer and Vaughan, 1996) for the control of hydraulic servo-systems. For a good performance and a high bandwidth control of a hydraulic actuator, a modern motion controller was required (Bobrow and Lum, 1996).

The electro-hydraulic actuator (EHA) is a new high-performance actuation system that combines the benefits of conventional hydraulic systems and direct-drive electrical actuators. It originally was developed for the aerospace industry and expanded applications into many other hydraulic industries. This device eliminates the need for separate hydraulic pumps and tubing, simplifying system structures and improving safety and reliability. EHA is a very 
promising device that has attracted a lot of research interest from its design to control (Alleyne and Liu, 2000; Habibi and Goldenberg, 2000; Liu and Alleyne, 2000; Niksefat and Sepehri, 2000) and the nonlinearities, system identification, model uncertainties, and disturbances (Ling et al., 2011; Lin et al., 2013). According to recent applications of EHA in Airbus A380 aircraft, engineers still face some unique problems with EHA (Van den Bossche, 2006), which include the performance and life of the pump, efficiency of the electric motor, reliability of the power electronics, and heat rejection problem. On Aug. 29, 2005, the A380 n ${ }^{\circ} 1$ flew for the first time simulating a dual hydraulic system failure, the control surfaces being driven by the EHA and electrical back-up hydraulic actuator. The aircraft operated with no significant difference in the servo control hydraulic system (Van den Bossche, 2006).

\subsection{Examples: fluid power systems}

Two examples of fluid power systems are presented in this section to give a general idea of modern fluid power techniques and applications. Technical details can be found in related references.

\subsubsection{Digital hydraulic systems}

In 2011 Prof. Scheidl and his colleagues presented a Forward Look article titled 'Is the future of fluid power digital?' (Scheidl et al., 2011) which is a response to Achten's Forward Look article 'Convicted to innovation in fluid power' in 2010 (Achten, 2010). Scheidl et al. (2011) believed that digital fluid power is a new branch of fluid power, which offers high potential for innovative solutions. And successful digital fluid power applications need new components, a comprehensive understanding of the system and novel control strategies or principles.

The digital hydraulic system has several advantages compared with continuous or analogue technologies, such as higher efficiency, precision, robustness, and reliability. It also offers new functionality that is impossible with existing fluid power systems, such as sensorless incremental actuation and digital control for multiple units' arrangements. Today, digital fluid power applications have gradually entered into our industries and market. It is certain that they will become much more digital and provide new opportunities for fluid power engineering in the future (Scheidl et al., 2011).
Hydraulic switching control is a sub-domain of digital hydraulics (Scheidl et al., 2013). An SIHS is a typical example of digital fluid power systems. It performs analogously to an electrical 'switched inductance' transformer, and is one possible approach to raise efficiency (Brown, 1987; Scheidl et al., 2008b; Johnston, 2009). This technique makes use of the inherent reactive behaviour of hydraulic components. A fluid volume can have a capacitive effect, whilst a small diameter line can have an inductive effect (Johnston, 2009). High-speed switching valves are needed to achieve the sufficient switching frequencies (Pan et al., 2014a; 2014b). It uses a fast switching valve to control flow or pressure, and is potentially very efficient as it does not rely on dissipation of power by throttling.

Fig. 3 shows two basic modes of SIHS, a flow booster and a pressure booster, which are configured by reversing the inlet and outlet connections in a three-port SIHS (Johnston, 2009). They consist of a long, small diameter 'inertance' tube and a highspeed switching valve with one common port, two switched ports, and an accumulator. The common port is connected alternately to the high pressure supply port and then the reservoir, operating cyclically and rapidly such that the high and low pressures are opened alternately. The delivery port might connect to a loading system, and includes an accumulator or other capacitance in order to maintain a constant loading pressure.

When the valve is connected to the highpressure supply port, flow passes from the high pressure supply to the delivery port and the fluid accelerates in the inertance line. When the valve is open to the reservoir, fluid is drawn from the reservoir to the delivery port by the momentum of the fluid in the inertance tube (Pan et al., 2014a; 2014b). As long as the valve is switched quickly, the delivery flow will only reduce slightly due to a small deceleration of fluid velocity when connected to the low-pressure supply, remaining a constant delivery flow. The physical characteristics of the SIHS provide the opportunity for high efficiency.

Digital pump development is another possible future trend in hydraulic systems. As most hydraulic system loads need variable flow for proper operation, it is conventional to control the flow using valves which alter the flow at the expense of energy loss. 


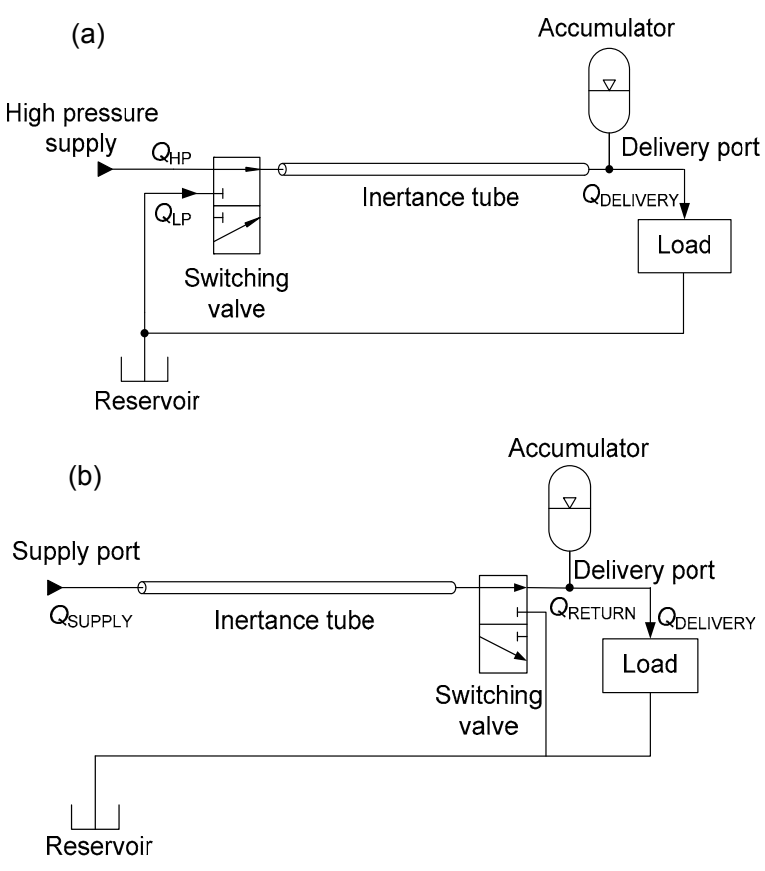

Fig. 3 Schematic diagram of SIHS: (a) Flow booster; (b) Pressure booster (Reprinted from (Pan et al., 2014b), Copyright 2014, with permission from SAGE)

$Q_{\mathrm{HP}}$ : flowrate from the high pressure supply port; $Q_{\mathrm{LP}}$ : flowrate from the low pressure supply port; $Q_{\text {DELIVERY }}$ delivery flowrate; $Q_{\text {RETURN }}$ : return flowrate; $Q_{\text {SUPPLY }}$ : supply flowrate

The digital displacement technique has been proposed for improving hydraulic system energy for transferring energy between mechanical and fluid power (Rampen et al., 1994; Ehsan et al., 2000; Linjama and Huhtala, 2009). Digital pump/motors aim to increase the efficiency and range of operation of fluid power systems by minimizing leakages, friction losses, and compressibility losses. Digital pumps can be implemented similarly to digital valves (Linjama, 2011). The fixed displacement pump is controlled by the high-speed switching on-off valve, which enables the flowrate to continuously switch between the main system and the reservoir. More generally, arranging digital pumps on the same axis and controlling by individual switching on-off valves, the flowrate can be modulated by using different control coding strategies. For the piston pump, the digital control technique is to control each piston of the pump independently by using switching on-off valves. It can be catalogued to the 'pure pump' and 'pump-motor' modes in terms of piston functions including pump, idle, and motor modes. The motor mode requires continuous switching of the control valves (Linjama, 2011). Artemis Intelligent Power Ltd. started research in the development of piston digital pump/motors in the 1980s and the first publications were in 1990 (Rampen and Salter, 1990). This technique enables innovative solutions for mobile equipment systems (Wadsley, 2011). The piston digital pump/motors research has also been investigated in Purdue University recently (Merrill and Lumkes, 2010; Merrill et al., 2013). The advantages and disadvantages of the different operating strategies and the design trade-offs for digital pump/ motors were studied.

\subsubsection{Hydraulic quadruped robots}

The MIT Leg Laboratory is well known for its milestone work of Prof. Marc Raibert, who showed in the 1980s that robotic running could be accomplished using appropriate control strategies and algorithms (Pratt, 2000). His 3D biped is shown in Fig. 4a. Later, Prof. Raibert left MIT to form Boston Dynamics which is an engineering and robotics design company that is best known for the development of BigDog, as shown in Fig. 4b. These two robots are hydraulically driven.

Boston Dynamics aims to build unmanned legged robots with rough-terrain mobility superior to existing wheeled and tracked vehicles. The ideal robot would travel anywhere a person or an animal could go using their legs, run for many hours at a time, and carry its own fuel and payload. It would be smart enough to negotiate terrain with a minimum of human guidance and intervention (Raibert et al., 2008). BigDog has onboard systems that provide power, actuation, sensing, controls, and communications. The power supply is a water-cooled two-stroke internal combustion engine that delivers about $15 \mathrm{hp}$ ( $1 \mathrm{hp}=746 \mathrm{~W})$. The engine drives a hydraulic pump which delivers high-pressure hydraulic oil through a system of filters, manifolds, accumulators, and other plumbing to the robot's leg actuators. It has about 50 sensors which measure the attitude, acceleration of the body, and motion and force of the actuators and also monitor BigDog's homeostasis. It has successfully performed different locomotion gaits, such as walking, trotting, and bounding, carried up to $154 \mathrm{~kg}$ payload and hiked for $2.5 \mathrm{~h}$ (Raibert et al., 2008). 
(a)

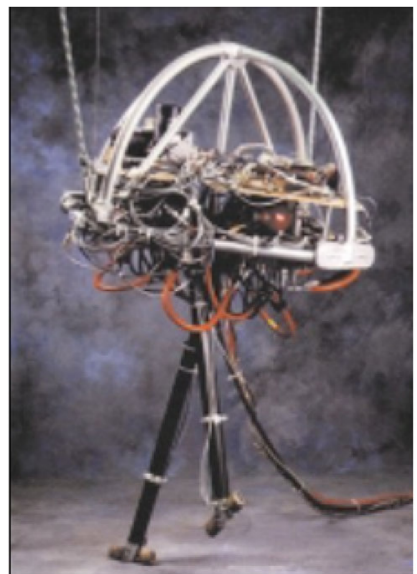

(b)

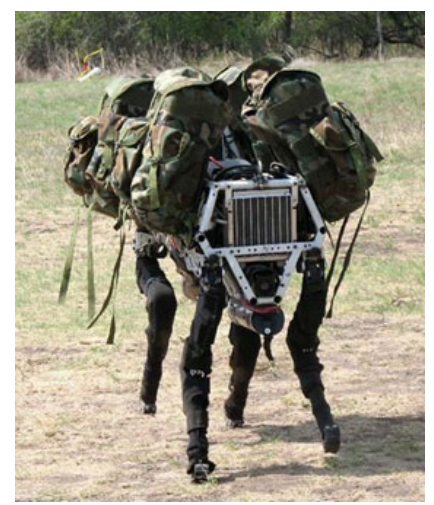

Fig. 4 Typical hydraulic driven robots (a) Marc Raibert's 3D biped (Image courtesy of Marc Raibert and the MIT Leg Laboratory, 1984) (Reprinted from (Pratt, 2000), Copyright 2000, with permission from IEEE); (b) BigDog-Boston Dynamics (http://en.wikipedia.org/wiki/ Boston_Dynamics)

Hydraulic Quadruped (HyQ) is a versatile hydraulically powered quadruped robot, which is developed for use as a platform to study the high dynamic motions and the navigation performance of the robot in the Italian Institute of Technology, Italy. Fig. 5 shows the photograph of the HyQ Leg and the CAD model of the robot body with the onboard hydraulic system. The design, component specifications, and experimental validation of the HyQ were described in (Semini et al., 2011).

The John Deere forestry walking machine is a prototype harvester used in the logging process, as shown in Fig. 6. The walking harvester was designed by John Deere's research and development unit in Finland in the 1990s (Available from $\mathrm{http}$ ://forestindustry.com/feature-article/world-s-firstprototype-walking-forest-machine-displayed-john- deere-pavilion). It aimed to create a machine that has the maximum working stability and minimum impact on challenging terrain, such as soft, sloping, and uneven conditions. The sensors in the six articulated legs react automatically to different terrain, while the computer control system controls all walking functions including the direction of movement, the travelling speed, the step height, and gait and the ground clearance. Each foot of the machine has a larger contact area than a conventional wheel, which spreads the load and decreases the amount of ground disturbance, while tires may leave grooves that channel rainwater and create erosion. The Timberjack measuring and control system is used to control the harvester head and the Timberjack Total Machine Control system is used to regulate the machine loader and engine functions in order to optimize machine operation. The operator-friendly controls are incorporated in a single joystick (Available from

(a)

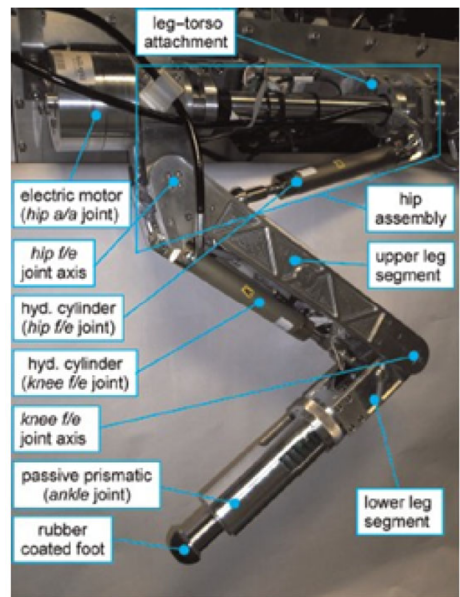

(b)

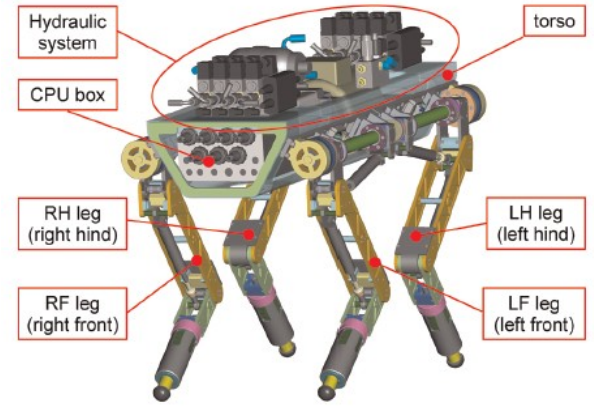

Fig. 5 Hydraulic Quadruped (HyQ) developed in Italian Institute of Technology, Italy (Reprinted from (Semini $e t$ al., 2011), Copyright 2011, with permission from SAGE ) (a) Photograph of the HyQ Leg; (b) CAD model of the robot body with the onboard hydraulic system 


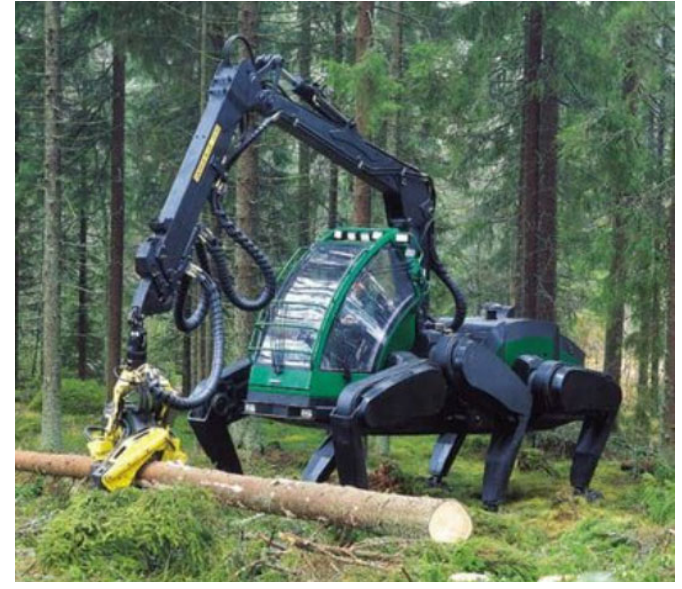

Fig. 6 John Deere walking machine

(http://www.likecool.com/Gear/Gadget/Logging\%20Spider/ Logging-Spider.jpg)

http://www.theoldrobots.com/Walking-Robot2.html). This innovative machine provides insight into new technologies that are being developed and could possibly change the future of the logging industry and pave the way for future developments in productive and environmentally friendly machines.

The researchers of the Korea Institute of Industrial Technology developed the hydraulic actuated quadruped walking robot qRT-2, which is the front drive machine with hydraulic linear actuators and wheeled back legs, as shown in Fig. 7a. The qRT-2 weighs about $60 \mathrm{~kg}$ and can carry over $40 \mathrm{~kg}$ of payload. It successfully demonstrated the trotting gaits at a speed up to $1.3 \mathrm{~m} / \mathrm{s}$ on an even surface and walking at $0.7 \mathrm{~m} / \mathrm{s}$ on an uneven and ramped surface (Kim et al., 2008). They also developed the 4-leg walking robot P2 in 2010 and investigated the hydraulic flow consumption during the robot's walking behaviour (Kim et al., 2010). A power optimization scheme on the minimization of the hydraulic flow consumption was applied in P2. Simulated and experimental results show very promising performance. All joints of the robotic legs are actuated by small size hydraulic rotary actuators, as shown in Fig. $7 \mathrm{~b}$.

In China, a hydraulic quadruped walking robot called 'Baby Elephant" was developed by Gao's research team (http://www.china.org.cn/china/201211/08/content_27042373.htm) in Shanghai Jiao Tong University. The robot weighs about $130 \mathrm{~kg}$ and its length, width, and height are $1.2 \mathrm{~m}, 0.5 \mathrm{~m}$, and $1 \mathrm{~m}$, respectively. It has 12 degrees of freedom for 4 legs controlled by hydraulic actuators. The lithium battery was applied as the power supply for the $10 \mathrm{~kW}$ high-performance motor which was used to drive the hydraulic pump (Chen et al., 2013). It can carry a heavy load and walk through the uneven terrain with a good stability. An energy storing mechanism was introduced in this robot, and the simulated and experimental results show its high efficiency (Chen et al., 2013). More investigation and experiments are continuing for the control strategies and gaits optimization. Another hydraulically actuated quadruped bionic robot was developed by the Robotics Centre of Shandong University. It aims to

(a)

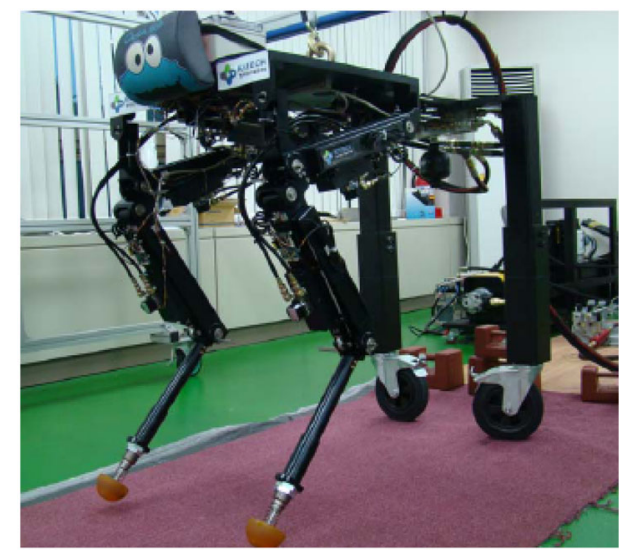

(b)

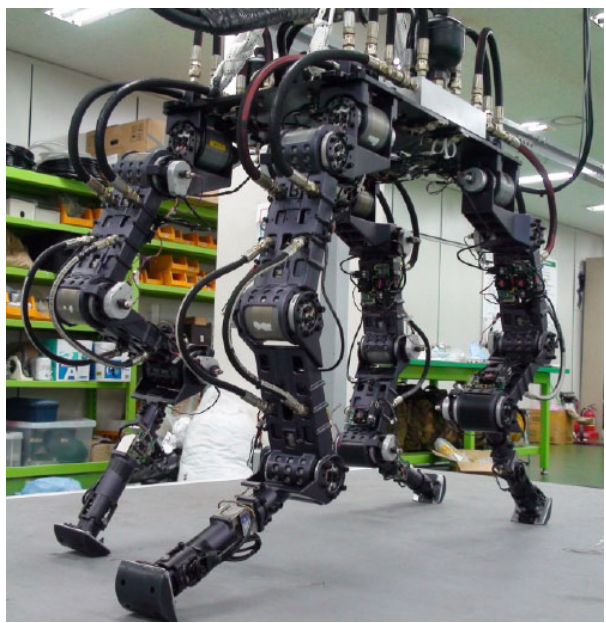

Fig. 7 Quadruped walking robots developed by Korea Institute of Industrial Technology

(a) A quadruped walking robot, qRT-2 (Reprinted from (Kim et al., 2008), Copyright 2008, with permission from IFAC); (b) A quadruped walking robot, P2 (Reprinted from (Kim et al., 2010), Copyright 2010, with permission from VDE VERLAG GMBH Berlin) 
develop a high dynamic quadruped robot which is able to work in complex terrains with good adaptability. It can walk with an average speed of $1 \mathrm{~m} / \mathrm{s}$ and a maximum speed of $1.8 \mathrm{~m} / \mathrm{s}$ without a heavy load and $0.4 \mathrm{~m} / \mathrm{s}$ with a load of $80 \mathrm{~kg}$ (Li et al., 2011). The research team in the Beijing Institute of Technology investigated the energy consumption of the designed quadrupedal robot and the results have been published in (Sha et al., 2013).

Good research outputs and achievements have been obtained in the last 20 years. Techniques such as terrain sensors, sophisticated computing, power systems, advanced actuators, and effective dynamic controls are still needed to meet the goals of ideal robot development.

\section{Development of fluid power in China}

\subsection{Market $^{1}$}

The mechanical industry is developing superfast in China. In the year 2010, the gross production value of domestic mechanical industry was about 14.38 trillion Yuan (CNY) in China, an increase of $33.79 \%$ on the year 2009 , as shown in Fig. 8. In 2010 , it delivered 380000 tractors, $130 \mathrm{GW}$ power generation equipment, 223900 Computer Numerical Control (CNC) manufacturing tools, 18.3 million automobiles, and 436.7 billion CNY of profit on the sales of construction machines. The growth rate of the gross domestic product (GDP) in China was 9\% during that period. A slight drop in the growth rate in 2009 can be noticed, due to the influence of the worldwide economic crisis.

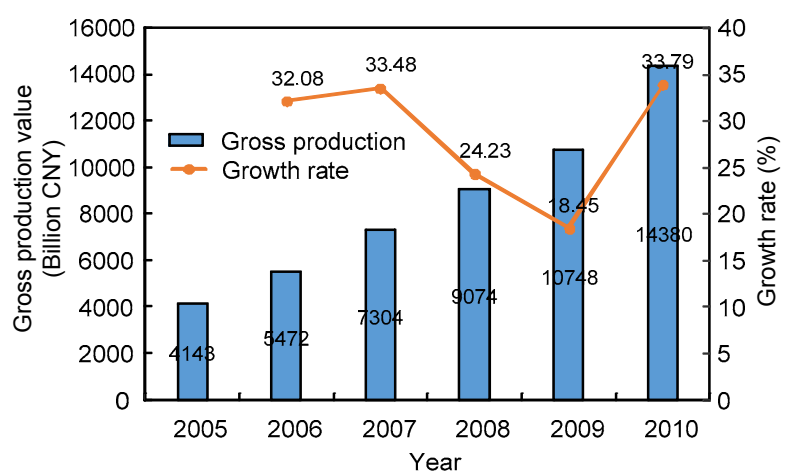

Fig. 8 Gross production value of domestic mechanical industry and its growth rate

\footnotetext{
${ }^{1}$ Related data in Section 3.1 was selected from the lecture (Yang, 2014)
}

Fig. 9 shows the total gross production value of fluid power areas, including hydraulics, pneumatics, and seals. As can be seen, the gross production value of these three main areas increased gradually from 2007 to 2013. The total value (hydraulics 49.4, pneumatics 18.50 , seals 24.5 billion CNY, respectively) reached 92.4 billion CNY in 2013. Again, in the year 2009, the growth rate in these three areas dropped because of the worldwide economic crisis and recovered in 2010 with rapid growth. The growth rate in the fluid power areas is shown in Fig. 10.

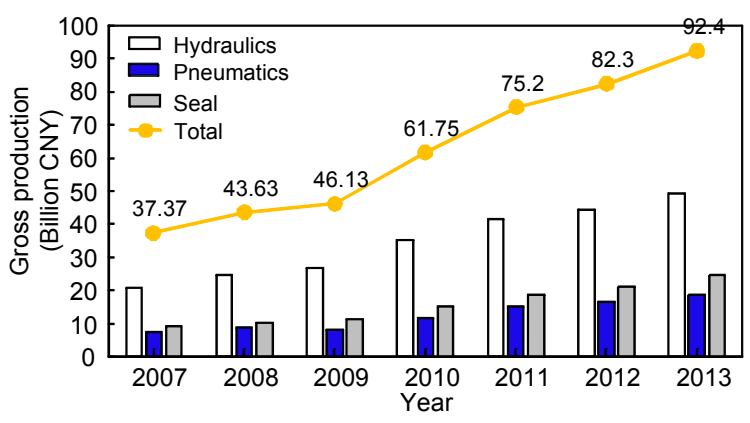

Fig. 9 Gross production value of the fluid power areas

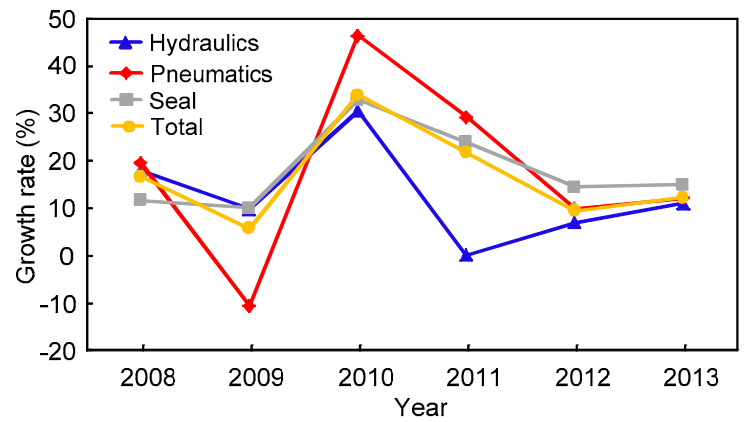

Fig. 10 Growth rate of the fluid power areas

In hydraulics in 2010, the percentage of pumps, motors, and cylinders (actuators) was $24 \%, 21 \%$, and $22 \%$, respectively, which occupied about a similar market share percentage. The total percentage of pumps, motors, and cylinders was $67 \%$ and it was more than two-thirds of the whole hydraulic product market. The percentages of hydraulic valves and systems were $14 \%$ and $19 \%$, respectively (Fig. 11).

Hydraulic products are widely applied in different areas, including construction machinery, aviation, metallurgical machinery, agricultural machinery, mining machinery, medical equipment, chemical 
devices, plastic machinery, shipbuilding, petroleum machinery, and automotive parts. The percentage of construction machinery and vehicles were $35.39 \%$ and $8.94 \%$ in 2010, as shown in Fig. 12. This is mainly due to the fast development of infrastructure in China in the last 10 years. The areas of market share below 4\% include medical equipment, chemical devices, plastic machinery, shipbuilding, petroleum machinery, and automotive engineering. It is because some of these areas are very specialized and the fluid power applications have only been introduced in recent years, such as for medical equipment and chemical devices. Also, modern hydraulic technology is a very important factor, which sometimes limited the development of some highly sophisticated areas in China, such as shipbuilding, petroleum machinery, and automotive parts. Therefore, it can be concluded that currently construction machinery and vehicles (44.33\%), aviation (9.49\%), metallurgical machinery $(9.35 \%)$, agricultural and mining machinery $(10.56 \%)$ are still occupying most of market share of hydraulic products.

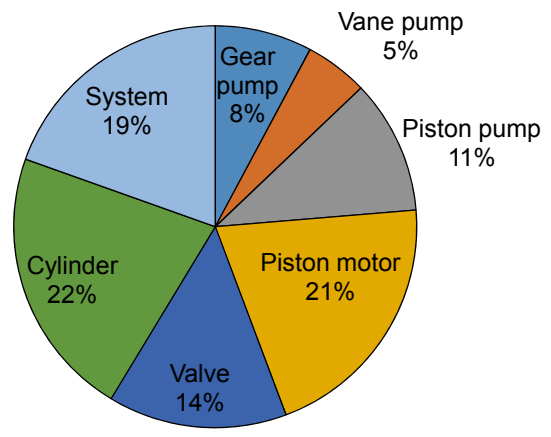

Fig. 11 Distribution of products in hydraulics in China in 2010

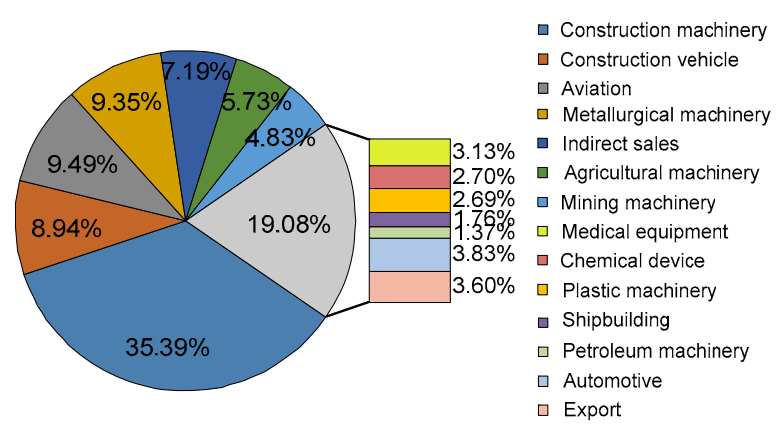

Fig. 12 Distribution of application areas of hydraulic machines in China in $\mathbf{2 0 1 0}$

\subsection{Research}

Fluid power research has developed very fast in universities and industry in China in the last decades. Table 3 shows the research centres and labs for fluid power and motion control in Chinese universities and their main research areas.

As can be seen, fluid power research is flourishing with the fast development of China. It covers a large range of fluid power engineering, from fundamental research to modern applications. More universities and industrial companies are stepping into fluid power areas, and the future of fluid power is very promising.

\section{Challenges and recommendations}

There are still many challenges in fluid power and motion control areas. The main challenges include its efficiency, compactness, and environmental impact. Overcoming these problems will dramatically improve the acceptability of fluid power and lead to its more widespread use.

\section{Energy efficiency}

Energy efficiency of fluid power systems is very significant. It has drawn the great attention of researchers and engineers (Murrenhoff et al., 2014). Highly efficient fluid power machines or devices can be achieved by using components with less energy loss, smart system design approaches, and clever control. Novel fluid power control methods are also needed to improve system efficiency.

\section{Compactness, integration, and weight}

The compactness and integration of fluid power machines or devices influence the development of fluid power systems. Portable and light human-scale fluid power devices, like personal service robots, lightweight fluid power components, are wanted by customers. Modern fluid power based compact power and actuation systems will provide greater energy and user convenience. Future work can be continued in the area of integration and compactness of fluid power systems, which will further improve the acceptability of fluid power.

\section{Quiet and clean}

Fluid power has been plagued by a number of factors that have prevented its wider acceptance (NSF, 2006). Our customers always request a clean, quiet, safe, and easy to use fluid power device. Fluid 
Table 3 Research centres and labs and areas and directions for fluid power and motion control in Chinese Universities* $^{*}$

\begin{tabular}{|c|c|c|}
\hline University & Research centres and labs & Research areas and directions \\
\hline $\begin{array}{l}\text { Zhejiang } \\
\text { University }\end{array}$ & $\begin{array}{l}\text { The State Key Laboratory of } \\
\text { Fluid Power Transmission } \\
\text { and Control; National En- } \\
\text { gineering Research Centre } \\
\text { of Electrohydraulic Con- } \\
\text { trol; The Institute of } \\
\text { Mechatronic Control } \\
\text { Engineering }\end{array}$ & $\begin{array}{l}\text { 1. Components } \\
\text { 1.1 Development of high performance hydraulic components; } \\
\text { 1.1.1 High pressure axial piston pump; high performance load } \\
\text { sensing pump; low noise high reliability piston pump } \\
\text { 1.1.2 High speed high flowrate electro-hydraulic valve; high per- } \\
\text { formance water hydraulic pump and valve; high performance } \\
\text { electro-mechanical elements } \\
\text { 1.2 Valve plate design; } \\
\text { 1.3 High-speed switching valve; } \\
\text { 1.4 High performance pneumatic components; } \\
\text { 2. Fundamental research } \\
\text { 2.1 Cavitation and complex flow; } \\
\text { 2.2 Noise and pressure pulsation reduction; } \\
\text { 2.3 Friction characteristics and piston materials; } \\
\text { 3. Motion control } \\
\text { 3.1 Accurate measurement approaches; } \\
\text { 3.2 Nonlinear position servo control; } \\
\text { 3.3 Precise motion control; } \\
\text { 4. Energy } \\
\text { 4.1 Renewable energy generator; } \\
\text { 4.2 Ocean engineering-hydraulic and mechatronic devices; } \\
\text { 5. Applications } \\
\text { 5.1 Research and development of tunnel boring machine; } \\
\text { 5.2 High performance mechatronic system; } \\
\text { 5.3 Bio-electro-mechanical systems }\end{array}$ \\
\hline $\begin{array}{l}\text { Harbin Institute of } \\
\text { Technology }\end{array}$ & $\begin{array}{l}\text { Department of Fluid Control } \\
\text { and Automation; Institu- } \\
\text { tion of Electrohydraulic } \\
\text { Simulation and Test } \\
\text { Systems }\end{array}$ & $\begin{array}{l}\text { Hydraulic servo-valve; } \\
\text { Electrohydraulic servo systems; } \\
\text { Innovative pneumatic components; } \\
\text { Fluid-structure coupling in hydraulic servo-valves }\end{array}$ \\
\hline $\begin{array}{l}\text { Beihang } \\
\text { University }\end{array}$ & $\begin{array}{l}\text { Department of Mechatronic } \\
\text { Control }\end{array}$ & $\begin{array}{l}\text { Active vibration suppression method in aircraft; } \\
\text { Advanced hydraulic components; } \\
\text { Life cycle management of hydraulic systems; } \\
\text { Electrohydraulic actuator }\end{array}$ \\
\hline $\begin{array}{l}\text { Yanshan } \\
\text { University }\end{array}$ & $\begin{array}{l}\text { Department of Mechatronic } \\
\text { Control Engineering }\end{array}$ & $\begin{array}{l}\text { Hydraulic control system of forging hydraulic press; } \\
\text { Wind power with fluid power control system; } \\
\text { Cold rolling mill precision hydraulic automatic gauge; control (hydrau- } \\
\text { lic automatic gauge control) system; } \\
\text { Intelligence control and safety and security of engineering machinery }\end{array}$ \\
\hline $\begin{array}{l}\text { Huazhong Univer- } \\
\text { sity of Science } \\
\text { and Technology }\end{array}$ & $\begin{array}{l}\text { Department of Fluid Power } \\
\text { Control }\end{array}$ & $\begin{array}{l}\text { Development of water hydraulic pumps; } \\
\text { Water hydraulic systems }\end{array}$ \\
\hline
\end{tabular}

power machines or devices with an effective human interface, low noise, and leakage are needed. A future requirement is to have operator control that is fast, precise, and intuitive, to have equipment that is quiet enough to not be obtrusive to the operator, and to have leaks that are so rare that they would have a negligible aesthetic and environmental impact.
Overcoming these problems will significantly improve the acceptability of fluid power and lead to its more widespread use.

\section{Fluid power education}

For many years, fluid power has been 'out of sight and out of mind', which was commented by Mr. Koski at a fluid power conference with concern 
about fluid power education (Koski, 1995). The same situation exists in China where not many universities or college-level engineering schools offer systematic fluid power degree courses. Our engineers working in fluid power areas have to start to learn basic knowledge after they have finished their degree courses in mechanical engineering. They normally know about fluid power engineering with a sudden realization that they are involved in the area of fluid power applications, such as construction machinery, agriculture machinery, mining, manufacturing, and aerospace engineering. In recent years, many universities realized this problem, and started to offer higher degree courses for fluid power engineering. Students have opportunities to study and research in this area with their final year projects, MSc projects, and $\mathrm{PhD}$ projects. It is a very promising development. However, most of the projects are directly based on applications, as shown in Table 3. The fundamental research in fluid power is only a small proportion in China. Academic staff, researchers and students focus on 'how to solve problems' rather than 'why something causes problems'. This will clearly limit the further development of fluid power engineering as we are still at the stage of making machines, rather than creating and understanding machines. More development in our fluid power education should be followed with an emphasis on fundamental research and applications of fluid power.

\section{Conclusions}

The domain of fluid power control can be expanded to a wider multi-disciplinary range, which can include efficiency, components design and optimisation, integration and compactness, environmental impact, and user-friendly and energy-efficient applications. Although we are facing challenges and competition from other areas such as mechanics or electricity, we still believe there is a very promising future as fluid power has its particular and significant advantages of high power density, high power-toweight ratio of actuators, system responsiveness, controllability, and versatility.

\section{References}

Achten, P., 2010. Convicted to innovation in fluid power. Proceedings of the Institution of Mechanical Engineers, Part I: Journal of Systems and Control Engineering, 224(6):619-621. [doi:10.1243/09596518JSCE1026]
Alleyne, A., Liu, R., 2000. A simplified approach to force control for electro-hydraulic systems. Control Engineering Practice, 8(12):1347-1356. [doi:10.1016/S09670661(00)00081-2]

Backé, W., 1993. The present and future of fluid power. Proceedings of the Institution of Mechanical Engineers, Part I: Journal of Systems and Control Engineering, 207(48):193-212. [doi:10.1243/PIME_PROC_1993_ 207_343_02]

Bobrow, J.E., Lum, K., 1996. Adaptive, high bandwidth control of a hydraulic actuator. Journal of Dynamic Systems, Measurement, and Control, 118(4):714-720. [doi:10. $1115 / 1.2802347]$

Brown, F.T., 1987. Switched reactance hydraulics: a new way to control fluid power. Proceedings of National Conference on Fluid Power, Chicago, USA, p.25-34.

Brown, F.T., Tentarelli, S.C., Ramachandran, S., 1988. A hydraulic rotary switched inertance servo-transformer. Journal of Dynamic Systems, Measurement, and Control, 110(2):144-150. [doi:10.1115/1.3152664]

Burrows, C.R., 1996. Fluid power systems design—Bramah's Legacy. Proceedings of the Institution of Mechanical Engineers, Part A: Journal of Power and Energy, 210(2): 105-120.

Burrows, C.R., 2000. Fluid power systems - some research issues. Proceedings of the Institution of Mechanical Engineers, Part C: Journal of Mechanical Engineering Science, 214(1):203-220.

Burrows, C.R., 2004. Fluid power-some reflections. The 6th International Conference on Hydraulic Machinery and Hydrodynamics, Timisoara, Romania, p.51-56.

Cao, J., Gu, L., Wang, F., et al., 2005. Switch mode hydraulic power supply theory. Proceedings of ASME International Mechanical Engineering Congress and Exposition, Orlando, Florida, USA.

Chen, X.B., Gao, F., Qi, C.K., et al., 2013. Energy storing mechanism for a new hydraulic motor actuated robot. Proceedings of the ASME International Design Engineering Technical Conferences and Computers and Information in Engineering Conference, Portland, Oregon, USA.

Devendran, R.S., Vacca, A., 2013. Optimal design of gear pumps for exhaust gas after treatment applications. Simulation Modelling Practice and Theory, 38:1-19. [doi:10.1016/j.simpat.2013.06.006]

Eaton, M., Keogh, P.S., Edge, K.A., 2006. The modelling, prediction, and experimental evaluation of gear pump meshing pressures with particular reference to aeroengine fuel pumps. Proceedings of the Institution of Mechanical Engineers, Part I: Journal of Systems and Control Engineering, 220(5):365-379. [doi:10.1243/ 09596518JSCE183]

Edge, K.A., 1997. The control of fluid power systemsresponding to the challenges. Proceedings of the Institution of Mechanical Engineers, Part I: Journal of Systems and Control Engineering, 211(2):91-110. [doi:10.1243/ 0959651971539920]

Ehsan, M., Rampen, W.H.S., Salter, S.H., 2000. Modelling of digital-displacement pump-motors and their application 
as hydraulic drives for nonuniform loads. ASME Journal of Dynamic Systems, Measurement, and Control, 122(1): 210-215. [doi:10.1115/1.482444]

Fales, R., 2005. Stability and performance analysis of a metering poppet valve. International Mechanical Engineering Congress and Exposition, Orlando, Florida, USA.

Fales, R., 2006. Stability and performance analysis of a metering poppet valve. International Journal of Fluid Power, 7(2):11-17. [doi:10.1080/14399776.2006.10781245]

Habibi, S., Goldenberg, A., 2000. Design of a new high performance electrohydraulic actuator. IEEE/ASME Transactions on Mechatronics, 5(2):158-164. [doi:10.1109/ 3516.847089]

Ivantysyn, J., Ivantysynova, M., 2003. Hydrostatic Pumps and Motors: Principles, Design, Performance, Modelling, Analysis, Control and Testing. Tech Books International.

Ivantysynova, M., 2008. Innovations in pump design-what are future directions? Proceeding of the 7th JFPS International Symposium on Fluid Power, Toyama.

Ivantysynova, M., Lasaar, R., 2004. An investigation into micro- and macrogeometric design of piston/cylinder assembly of swash plate machines. International Journal of Fluid Power, 5(1):23-36. [doi:10.1080/14399776. 2004.10781181]

Johnston, D.N., 2009. A switched inertance device for efficient control of pressure and flow. ASME/Bath Fluid Power Symposium: Valve Design and Analysis, Hollywood, USA, p.589-596. [doi:10.1115/DSCC2009-2535]

Johnston, D.N., Edge, K.A., Vaughan, N.D., 1991. Experimental investigation of flow and force characteristics of hydraulic poppet and disc valves. Proceedings of the Institution of Mechanical Engineers, Part A: Journal of Power and Energy, 205(3):161-171.

Khoshzaban Zavarehi, M., 1999. Nonlinear modeling and validation of solenoid-controlled pilot-operated servovalves. IEEE/ASME Transactions on Mechatronics, 4(3): 324-334. [doi:10.1109/3516.789690]

Kim, H.K., Won, D., Kwon, O., et al., 2008. Foot trajectory generation of hydraulic quadruped robots on uneven terrain. Proceedings of the 17th International Federation of Automation Control, Seoul, Korea, p.3021-3026.

Kim, T.J., So, B., Kwon, O., et al., 2010. The energy minimization algorithm using foot rotation for hydraulic actuated quadruped walking robot with redundancy. Proceedings of the 41st International Symposium on Robotics and 6th German Conference on Robotics, Munich, Germany, p.786-791.

Kogler, H., Scheidl, R., 2008. Two basic concepts of hydraulic switching converters. The 1st Workshop on Digital Fluid Power, Tampere, Finland.

Koski, R.E., 1995. Fluid power education —what went wrong? Proceedings of 4th Scandinavian International Conference on Fluid Power, Tampere, Finland, p.71-92.

Krus, P., Jansson, A., Palmberg, J.O., 1991. Optimization for component selection in hydraulic systems. The 4th Bath International Fluid Power Workshop, Bath, UK.

Krus, P., Weddfelt, K., Palmberg, J.O., 1994. Fast pipeline models for simulation of hydraulic systems. Journal of
Dynamic Systems, Measurement, and Control, 116(1): 132-136.

Kudzma, S., Johnston, D.N., Plummer, A., et al., 2012. A high flow fast switching valve for digital hydraulic systems. The 5th Workshop on Digital Fluid Power, Tampere, Finland.

Lasaar, R., Ivantysynova, M., 2002. Advanced gap designbasis for innovative displacement machines. 3rd International Fluid Power Conference, Aachen, Germany, p.215-229.

Li, Y.B., Li, B., Rong, X.W., et al., 2011. Mechanical design and gait planning of a hydraulically actuated quadruped bionic robot. Journal of Shandong University (Engineering Science), 41(5):32-36 (in Chinese). [doi:10.1007/ s11741-011-0682-3]

Lin, Y., Shi, Y., Burton, R., 2013. Modeling and robust discrete time sliding mode control design for a fluid power electrohydraulic actuator system. IEEE/ASME Transactions on Mechatronics, 18(1):1-10. [doi:10.1109/ TMECH.2011.2160959]

Ling, T.G., Rahmat, M.F., Husain, A.R., et al., 2011. System identification of electro-hydraulic actuator servo system. 4th International Conference on Mechatronics, p.1-7.

Linjama, M., 2011. Digital fluid power-state of the art. The 12th Scandinavian International Conference on Fluid Power, Tampere, Finland.

Linjama, M., Huhtala, K., 2009. Digital pump-motor with independent outlets. Proceedings of the 11th Scandinavian International Conference on Fluid Power, Linköping, Sweden.

Liu, R., Alleyne, A., 2000. Nonlinear force/pressure tracking of an electro-hydraulic actuator. Journal of Dynamic Systems, Measurement, and Control, 122(1):232-236. [doi:10.1115/1.482466]

Manring, N.D., 2003. Valve-plate design for an axial piston pump operating at low displacements. Journal of $\mathrm{Me}$ chanical Design, 125(1):200-205. [doi:10.1115/1. 1541632]

Manring, N.D., Zhang, Y., 2001. The improved volumetricefficiency of an axial-piston pump utilizing a trappedvolume design. Journal of Dynamic Systems, Measurement, and Control, 123(3):479-487. [doi:10.1115/1. 1389311]

Mauck, L.D., Menchaca, J., Lynch, C.S., 2000. Piezoelectric hydraulic pump development. Wereley, N.M. (Ed.), Smart Structures and Materials: Smart Structures and Integrated Systems, Newport Beach, USA, p.729-739. [doi:10. 1117/12.388881]

Merrill, K.J., Lumkes, J., 2010. Operating strategies and valve requirements for digital pump/motors. Proceedings of the 6th FPNI-PhD Symposium, West Lafayette, p.249-258.

Merrill, K.J., Breidi, F.Y., Lumkes, J.Jr., 2013. Simulation based design and optimization of digital pump/motors. Proceedings of the ASME/BATH Symposium on Fluid Power \& Motion Control, Sarasota, Florida, USA.

Muller, M.T., Fales, R.C., 2008. Design and analysis of a two-stage poppet valve for flow control. International Journal of Fluid Power, 9(1):17-26. [doi:10.1080/ 14399776.2008.10781293] 
Murrenhoff, H., 2007. Trends and some recent developments in mobile hydraulics. Institute for Fluid Power Drives and Controls, RWTH Aachen University, Germany.

Murrenhoff, H., Sgro, S., Vukovic, M., 2014. An overview of energy saving architectures for mobile applications. Proceedings of the 9th International Fluid Power Conference, Aachen, Germany.

NSF (National Science Foundation), 2006. Strategic Implementation Plan, Engineering Research Center for Compact and Efficient Fluid Power. NSF, USA.

Niksefat, N., Sepehri, N., 2000. Design and experimental evaluation of a robust force controller for an electrohydraulic actuator via quantitative feedback theory. Control Engineering Practice, 8(12):1335-1345. [doi:10. 1016/S0967-0661(00)00075-7]

Opdenbosch, P., Sadegh, N., Book, W.J., 2004. Modeling and control of an electro-hydraulic poppet valve. Proceeding of IMECE, Anaheim, USA, p.103-110.

Opdenbosch, P., Sadegh, N., Book, W.J., 2008. Learning control applied to electro-hydraulic poppet valves. American Control Conference, Seattle, USA, p.15251532.

Opdenbosch, P., Sadegh, N., Book, W., et al., 2009. Modeling an electro-hydraulic poppet valve. International Journal of Fluid Power, 10(1):7-15. [doi:10.1080/ 14399776.2009.10780963]

Pan, M., Johnston, D.N., Plummer, A., et al., 2014a. Theoretical and experimental studies of a switched inertance hydraulic system. Proceedings of the Institution of $\mathrm{Me}$ chanical Engineers, Part I: Journal of Systems and Control Engineering, 228(1):12-25. [doi:10.1177/ 0959651813500952]

Pan, M., Johnston, D.N., Plummer, A., et al., 2014b. Theoretical and experimental studies of a switched inertance hydraulic system including switching transition dynamics, non-linearity and leakage. Proceedings of the Institution of Mechanical Engineers, Part I: Journal of Systems and Control Engineering, 228(10):802-815. [doi:10.1177/ 0959651814548299]

Plummer, A., Vaughan, N., 1996. Robust adaptive control for hydraulic servosystems. ASME Journal of Dynamic Systems, Measurement, and Control, 118(2):237-244. [doi:10.1115/1.2802309]

Pohl, J., Sethson, M., Krus, P., et al., 2001. Modelling and simulation of a fast $2 / 2$ switching valve. 5th International Conference on Fluid Power Transmissions and Control, Hangzhou, China, p. 2-22.

Pratt, G.A., 2000. Legged robots at MIT: what's new since Raibert? IEEE Robotics and Automation Magazine, p.15-19.

Raibert, M., Blankespoor, K., Nelson, G., et al., 2008. BigDog, the rough-terrain quadruped robot. Proceedings of the 17th World Congress, The International Federation of Automatic Control, Seoul, Korea.

Rampen, W.H.S., Salter, S.H., 1990. The digital displacement hydraulic piston pump. Proceedings of the 9th International Symposium on Fluid Power, BHR Group, Cambridge, STI, UK, p.33-46.
Rampen, W.H.S., Almond, J.P., Salter, S.H., 1994. The digital displacement pump/motor operating cycle: experimental results demonstrating the fundamental characteristics. 7th International Fluid Power Workshop, Bath, p.321-331.

Reuter, J., Maerkl, S., Jaekle, M., 2010. Optimized control strategies for fast switching solenoid valves. International Journal of Fluid Power, 11(3):23-33. [doi:10. 1080/14399776.2010.10781012]

Scheidl, R., Manhartsgruber, B., Kogler, H., et al., 2008a. The hydraulic buck converter-concept and experimental results. Proceedings of the 6th International Conference on Fluid Power, Dresden, Germany.

Scheidl, R., Manhartsgruber, B., Winkler, B., 2008b. Hydraulic switching control- principles and state of the art. The 1st Workshop on Digital Fluid Power, Tampere, Finland.

Scheidl, R., Linjama, M., Schmidt, S., 2011. Is the future of fluid power digital? Proceedings of the Institution of Mechanical Engineers, Part I: Journal of Systems and Control Engineering, 226(6):721-723.

Scheidl, R., Kogler, H., Windler, B., 2013. Hydraulic switching control-objectives, concepts, challenges and potential applications. Magazine of Hydraulics, Pneumatics, Tribology, Ecology, Sensorics, Mechatronics, p.7-18.

Schoenau, G.J., Burton, R.T., Kavanagh, G.P., 1990. Dynamic analysis of a variable displacement pump. Journal of Dynamic Systems, Measurement, and Control, 112(1): 122-132. [doi:10.1115/1.2894129]

Semini, C., Tsagarakis, N.G., Guglielmino, E., et al., 2011. Design of HyQ-hydraulically and electrically actuated quadruped robot. Proceedings of the Institution of $\mathrm{Me}$ chanical Engineers, Part I: Journal of Systems and Control Engineering, 225(6):831-849. [doi:10.1177/ 09544054JEM2115]

Sha, S., Pan, S.P., Wang, J.Z., et al., 2013. Coupled drive leg of quadrupedal robot mechanism design and analysis of energy consumption. International Conference on Mechatronic Sciences, Electric Engineering and Computer, Shenyang, China.

Sirohi, J., Chopra, I., 2003. Design and development of a high pumping frequency piezoelectric hydraulic hybrid actuator. Journal of Intelligent Materials Systems and Structures, 14(3):135-147. [doi:10.1177/1045389X03014 003002]

Sohl, G.A., Bobrow, J.E., 1999. Experiments and simulations on the nonlinear control of a hydraulic servosystem. IEEE Transactions on Control Systems Technology, 7(2):238-247.

Tao, G., Chen, H.Y., He, Z.B., 2002. Optimal design of the magnetic field of a high-speed response solenoid valve. Journal of Materials Processing Technology, 129(1-3): 555-558. [doi:10.1016/S0924-0136(02)00633-7]

Tsao, T., Tomizuka, M., 1994. Robust adaptive and repetitive digital tracking control and application to a hydraulic servo for noncircular machining. ASME Journal of Dynamic Systems, Measurement, and Control, 116(1):2432. [doi:10.1115/1.2900676]

Tu, H.C., Rannow, M., Van de Ven, J., et al., 2007. High speed rotary pulse width modulated on/off valve. 
Proceedings of the ASME International Mechanical Engineering Congress, Seattle, Washington, USA, p.1-14.

Tu, H.C., Rannow, M.B., Wang, M., et al., 2012. Design, modelling, and validation of a high-speed rotary pulsewidth-modulation on/off hydraulic valve. ASME Journal of Dynamic Systems, Measurement, and Control, 134(6): 061002. [doi:10.1115/1.4006621]

Van den Bossche, D., 2006. The A380 flight control electro hydrostatic actuators, achievements and lessons learnt. 25th International Congress of the Aeronautical Sciences, p.1-8.

Vaseena, A., Vacca, A., 2010. Design optimization of the sliding elements of external gear machines. 6th FPNIPhD Symposium, West Lafayette, USA.

Vaughan, N.D., Gamble, J.B., 1996. The modeling and simulation of a proportional solenoid valve. Journal of $D y$ namic Systems Measurement and Control, 118:120-125. [doi:10.1115/1.2801131]

Vaughan, N.D., Johnston, D.N., Edge, K.A., 1992. Numerical simulation of fluid flow in poppet valves. Proceedings of the Institution of Mechanical Engineers, Part C: Journal of Mechanical Engineering Science, 206(2):119-127.

Wadsley, L., 2011. Optimal system solutions enabled by digital pumps. The 52nd National Conference on Fluid Power.

Wang, Q., Yang, F., Yang, Q., et al., 2011. Experimental analysis of new high-speed powerful digital solenoid valves. Energy Conversion and Management, 52(5): 2309-2313. [doi:10.1016/j.enconman.2010.12.032]

Watton, J., 2009. Fundamentals of Fluid Power Control. Cambridge University Press, p.11-15.

Wieczorek, U., Ivantysynova, M., 2002. Computer aided optimization of bearing and sealing gaps in hydrostatic machines - the simulation tool CASPAR. International Journal of Fluid Power, 3(1):7-20. [doi:10.1080/ 14399776.2002.10781124]

Winkler, B., 2004. Development of a fast low-cost switching valve for big flow rates. 3rd PFNI-PhD Symposium on Fluid Power, Terrassa, Spain.

Winkler, B., Scheidl, R., 2007. Development of a fast seat type switching valve for big flow rates. The 10th Scandinavian International Conference on Fluid Power, Tampere, Finland.

Xiong, Y., Wei, J.H., Feng, R.L., 2015. Adaptive robust control of a high-response dual proportional solenoid valve with flow force compensation. Proceedings of the Institution of Mechanical Engineers, Part I: Journal of Systems and Control Engineering, 229(1):3-26. [doi:10. 1177/0959651814549647]

Yamaguchi, A., 1966. Studies on the characteristics of axial plunger pumps and motors: 1st Report, Effects of trapping phenomena on the characteristics. Bulletin of Japan Society of Mechanical Engineers, 9(34):305-313. [doi:10. 1299/jsme1958.9.305]

Yang, H.Y., 2014. Recent fluid power research activities in China. 9th International Fluid Power Conference, Aachen, Germany.

Zeiger, G., Akers, A., 1985. Torque on the swash plate of an axial piston pump. Journal of Dynamic Systems, Measurement, and Control, 107(3):220-226. [doi:10.1115/ $1.3140724]$

\section{中文概要}

题 目: 流体动力工程研究综述

概 要: 本综述详细介绍近年来流体传动技术的发展现 状, 特别是该学科在中国的研究开展现状以及 应用市场。同时详细讨论液压泵、阀及执行元 件的发展与新技术, 以及液压惯性切换系统和 液压四足机器人两个典型的现代流体传动系 统。并从液压系统效率、集成一体化、系统清 洁和流体传动学科教育四个方面讨论当前研究 人员所面临的挑战, 并提出相关建议。

关键词: 流体传动; 液压系统效率; 液压蜃; 液压阀; 液压执行元件; 液压惯性切换系统; 液压四足 机器人; 流体传动学科教育

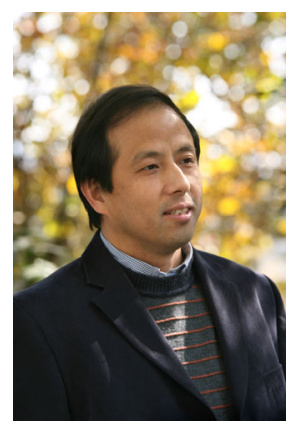

\section{Introducing Editor-in-Chief:}

Prof. Hua-yong YANG has been the Editor-in-Chief of Journal of Zhejiang University-SCIENCE A (Applied Physics \& Engineering) since 2014. He is the Cheung Kong Chair Professor of Zhejiang University, and has been a member of the Chinese Academy of Engineering since 2013. He is also a Fellow of the Chinese Mechanical Engineering Society. He is again the director of the State Key Laboratory of Fluid Power Transmission and Control at Zhejiang University since March 2014, and he was the director of the laboratory previously in 1997 to 2001 . He is also an active expert for fluid power related industries and various government agencies in China.

Prof. YANG received his BSc degree from Huazhong University of Science and Technology, China in 1982 and his $\mathrm{PhD}$ degree from University of Bath, UK in 1988. He is a prolific researcher with 139 invention patents, 3 (co)authored academic books, and over 240 technical papers published in international journals and conferences. He is active in major international conferences related to both fluid power and mechatronics. He has been a member in the Technical Program Committee of international conferences, such as 2011 IEEE/ASME International Conference on Advanced Intelligent Mechatronics, and also the IPC co-chair of 2013 International Federation of Automatic Control (IFAC) Symposium on Mechatronic Systems. His research interests are in motion control and energy saving of mechatronic systems, fluid power component, and system development. 